\title{
A EXPRESSÃO LITÚRGICA DA ROMARIA EM JUAZEIRO DO NORTE - CEARÁ ${ }^{1}$
}

\author{
Dom Fernando Panico
}

\section{RESUMO}

No nordeste brasileiro, o caminho de dois milhões e meio de romeiros leva todos os anos, a Juazeiro do Norte, a Terra Prometida e da salvação dos pobres, ao encontro da Mãe das Dores e do santo conselheiro e Padrinho, o Pe. Cícero Romão Batista. Este estudo busca um diálogo entre o que chamamos de "liturgia romeira" e a liturgia que se celebra em todas as nossas comunidades de fé em vista de uma mútua fecundação.

Palavras chaves: "liturgia romeira", "espacialidade sagrada", cultura do povo, busca, esperança, salvação.

\begin{abstract}
In northeastern Brazil, the path of two and a half million pilgrims leads Every year, to North Juazeiro, the Promised Land and the salvation of the poor to meet the Mother of Sorrows and Holy Godfather and adviser, the Rev. father Cicero Romão Batista. This study seeks a dialogue between what we call "liturgy cape" and liturgy which is celebrated in all our communities of faith, In view of a mutual fertilization.
\end{abstract}

Key words: "liturgy cape", "sacred spatiality," culture of the people, search, hope, salvation.

\footnotetext{
1 Este estudo, em vista da assessoria do XX Encontro da ASLI - Associação dos Liturgistas do Brasil, com o tema Romarias, piedade popular e liturgia, realizado em Cachoeira do Campo, Diocese de Mariana, MG, em 2009, quer revelar a "primeira teologia" escondida nos segredos do coração de uma "nação romeira" que celebra sua fé em Cristo mediante a linguagem simbólica própria da sua tradição eclesial e cultural. É uma tentativa de promover um frutuoso diálogo e um intercâmbio de luzes e de esperanças, entre a liturgia romeira e a ciência litúrgica, face aos questionamentos e desafios da Liturgia, hoje.
} 


\title{
INTRODUÇÃO
}

\author{
Romaria: \\ poesia em gesto que encanta a vida \\ e celebra a fé dos pobres.
}

A romaria, povo de Deus a caminho, revela os desígnios de Deus na História. E o faz como em poesia: condensa, interroga, nos questiona. Desvela um mundo verdadeiro que não se reduz à mera descrição ou conceito. Dá provas do limite da linguagem. Une céu e terra. Testemunha. Brinca com o tempo porque olha o passado, mas projeta o futuro: confia e espera fé e esperança.

O tempo peregrino e romeiro é o tempo da Graça. Esse tempo é vivido no abandono da rotina do dia-a-dia para se conquistar uma experiência extraordinária e do Outro. É o tempo oportuno, o tempo da liberdade. A partida romeira e peregrina já é em si mesma, um ato de fé, de esperança e de busca. A decisão de ir até o fim do caminho cria um espaço interior e pessoal de acolhida, no qual as dificuldades encontradas e sua superação, representam no coração dos romeiros e peregrinos, uma vitória sobre as hostilidades do mundo impostas socialmente às suas vidas. É tempo do mistério." 2

Mas é também tempo de poesia. Do mundo de sempre, numa nova linguagem. Mundo novo para o qual Deus os chama. "Lugar sagrado" onde a Boa Nova faz sentido.

As romarias falam da Revelação do Deus vivo que os romeiros(as) trazem consigo pelas estradas ao caminharem juntos na gratuidade da obediência a um chamado que vem do alto através de Nossa Senhora e na aventura de uma "fé peregrina", como a do Pai Abraão, iluminada pelo Mistério da Cruz. Finalmente, após uma viagem incômoda e longa, a chegada a Juazeiro é vivida como a entrada dos pobres na festa da Jerusalém celeste do Nordeste. Declamando sua poesia em gestos, benditos e ritos romeiros, os peregrinos dão glória a Deus e buscam a salvação que vem da Cruz redentora do Senhor. A esta riqueza de fé vivida, sofrida, cantada e celebrada quero chamar aqui, em linguagem simbólica, de "liturgia romeira". O termo

2 PANICO, Fernando. "Romarias e Reconciliação". Carta Pastoral, 2003 . n 22. 
é sugestivo na expressão e no significado. Este verbete não se encontra nos dicionários clássicos da "teologia segunda", e sim na experiência da fé encarnada na vida do povo, a "primeira teologia".

\section{PRIMEIRA PARTE}

\section{ORIGEM DAS ROMARIAS EM JUAZEIRO DO NORTE.}

A história de Juazeiro se confunde com o fenômeno das romarias. A cidade nasceu à sombra da árvore que lhe deu o nome e tornou-se sacramento da devoção popular, lugar de encontro para reavivar e celebrar a fé do povo que caminha com Cristo e com a Igreja, nas estradas do Nordeste brasileiro, rumo a Jerusalém celeste.

As romarias começaram a acontecer quando Padre Cícero, recém ordenado presbítero, assumiu o lugar de capelão no lugarejo Tabuleiro Grande (hoje Juazeiro do Norte), obedecendo a um sonho místico, sonho fundador, no qual Jesus Cristo Ihe pedia para tomar conta dos pobres do lugar. Era o dia 11 de abril de 1872. Depois de ter atendido muitos fiéis no confessionário, o Pe. Cícero, vencido pelo cansaço, foi descansar um pouco. Durante a soneca, sonhou que the aparecia Jesus, acompanhado dos doze Apóstolos, como no painel famoso da Santa Ceia de Leonardo da Vinci. O Cristo deixava entrever também o seu coração exposto como nas estampas e imagens que propagavam a devoção ao Sagrado Coração de Jesus. 0 Mestre recrimina a ingratidão dos homens e reafirma sua disposição de dar mais uma chance de salvação à humanidade pecadora. O quadro se completa com o surgimento de um grupo de flagelados maltrapilhos e esfomeados. O Cristo, de coração exposto (Sagrado Coração de Jesus), volta-se então para o Pe. Cícero e diz: "E tu, Cícero, cuida deles!".

Conforme um amigo seu, o Padre Cícero

acordou-se sob tal impressão e depois, notando que os sertanejos das circunvizinhanças cada vez mais procuravam suas 
missões, missas e confissões, creu que estava escolhido por desígnios superiores. ${ }^{3}$

Uma cidade nasceu para abrigar conforme o mandato de Jesus Cristo, os pobres do lugar, porque Padre Cícero acreditou no desígnio de Deus. Com seu carisma acolhia, protegia, aconselhava, repreendia as pessoas que, em grande número, já o procuravam para ouvir a palavra de Deus. Por isso decidiu reconstruir a capela que estava ruindo. Como dizia Dom Joaquim, o então Bispo do Ceará, um "templo vasto e arquitetônico" foi levantado. Isso foi possível com a ajuda dos pobres que para ali acorriam e que estavam acostumados a serem convocados pelo Padre Ibiapina cuja ação missionária, em tempos idos, abrangia todo sertão e foram "treinados" a construir ou reformar igrejas, capelas, cemitérios, orfanatos, açudes, casas de caridade.... Sempre em mutirão, sempre em nome da "santa religião".

\section{II - JUAZEIRO 'LUGAR DE SALVAÇÃO’}

Se o sonho selou o destino do jovem presbítero, vinculando-o ao povoado, a um povo de migrantes e flagelados pelas secas periódicas do Nordeste, foi no entanto, o milagre protagonizado pela beata Maria Magdalena do Espírito Santo de Araujo a pedra fundamental na construção do Juazeiro como cidade santa, Nova Jerusalém, porto de salvação, Terra Prometida. O fato extraordinário da hóstia, sangrando por ocasião da comunhão da beata, aconteceu pela primeira vez antes da celebração da missa, na madrugada de uma primeira sexta feira de março de 1889, no tempo litúrgico da Quaresma. O fenômeno se repetiu muitas vezes nos quatro anos seguintes (1889 a 1893), geralmente durante a quaresma, e desencadeou a chamada questão religiosa do Joazeiro, pois atraía multidões de romeiros de todos os Estados do Nordeste.

O sangramento da hóstia provocou o surgimento de romarias organizadas para Juazeiro. A reação do Bispo do Ceará não demorou. Os assim chamados "fenômenos religiosos" em Juazeiro foram desqualificados como religiosos e admitidos como fraude grosseira e supersticiosa. Esta é a pá-

3 DINIZ, M. Mistérios do Juazeiro, Juazeiro: Tipografia de "O Joazeiro", 1934, p. 6 CE. p. 6. Este autor foi muito amigo de Pe. Cícero e freqüentemente, como ele mesmo diz, "aos domingos e feriados", visitava o Padre. Das suas conversas, escreveu este livro, editado no ano da morte de Pe. Cícero. 
gina mais dolorosa de uma história que precisa ser recontada. Até hoje, os romeiros mantêm "silêncio obsequioso" sobre o fato da Hóstia, em obediência ao Pe. Cícero que Ihes pediu para não se falar sobre o assunto, por fidelidade à Igreja.

Em suas comunicações à beata Maria de Araújo e ao Padre Cícero, o próprio Jesus desvenda o mistério escondido nos fenômenos religiosos de Juazeiro:

Jesus Christo(sic) me tem revelado que tudo isso se opera para conversão dos pecadores (sic) e perseverança dos justos; chegando até queixar-se amargamente da ingratidão dos homens para com Elle (sic) e chamando-os a aproveitarem-se de suas graças enquanto (sic) é tempo de mizericordia (sic) () em algumas dessas revelações indica-lhe querer fazer deste lugar (sic) uma porta do céu (sic) e um logar (sic) de salvação para as almas. (). ${ }^{4}$

A notícia da manifestação do amor de Deus para com aqueles que desejavam se converter e procuravam o perdão e o alimento para sua fé, correu os sertões como fogo em rastilho de pólvora. E o povo respondeu ao carinhoso chamamento de Deus, indo numeroso e com toda dificuldade para o "lugar de salvação para as almas". A primeira romaria organizada partiu da cidade do Crato, tendo à frente Mons. Monteiro e se realizou no dia 7 de julho, festa do Preciosíssimo Sangue, conforme o antigo calendário litúrgico. Portanto, as romarias, neste ano de 2009, completam 120 anos.

Também nos nossos dias, os romeiros continuam afluindo a Juazeiro do Norte, movidos pela fé. No imaginário religioso-popular, Juazeiro é a cidade acolhedora "dos náufragos da vida" (como o Pe. Cícero dizia) e, portanto, lugar abençoado, sonhado e amado como um "santuário a céu aberto", "cidade santa", a Jerusalém celeste aqui na terra, a Roma dos pobres, Terra da Mãe de Deus e do Pe. Cícero, "lugar de salvação". Isto é comprovado pelo seguinte depoimento de uma romeirinha de Maceió, Arlene, quando com quinze anos de idade, em 1981, visitou Juazeiro pela primeira vez:

Quando minha viagem foi marcada para vir ao Juazeiro, meu pai disse para mim que, naquele tempo que faltava, não era

4 Depoimento da Beata Maria de Araújo em 9 de Setembro de 1891. Inquérito I, p.21. 
para fazer nada de errado, nem chamar apelido, porque a gente vinha para um lugar santo. Eu fiquei curiosa para saber como era esse lugar tão santo como o povo chamava. () Quando entramos no Juazeiro, eu pensava: agora sim, estou entrando no Santo Lugar da Mãe das Dores e de meu padrinho Padre Cícero. Meu coração ficou cheio de alegria, de felicidade e eu esqueci de tudo, até da família. ${ }^{5}$

\section{III - OS SUJEITOS DA LITURGIA ROMEIRA}

As Romarias de Juazeiro são as únicas no Brasil de cunho eminentemente popular. Os romeiros e romeiras, apesar de toda perseguição e discriminação sofrida, tanto em Juazeiro como em seus locais de origem, apesar de toda desqualificação recebida, persistiram, resistiram, permaneceram e permanecem fiéis à Igreja católica, seguindo o exemplo do Pe. Cícero.

Pe. Francisco Murilo de Sá Barreto, falecido em 2005, Pároco da Matriz de Juazeiro durante 47 anos, carinhosamente chamado de "vigário do nordeste", pela sua acolhida sempre amorosa e perseverante aos romeiros, nos ajuda a reconhecer quem são eles:

Crianças, jovens, casais, famílias, trabalhadores da roça, das cidades, pessoas simples que pouco colocam de racionalização na expressão de sua fé e muito confiam na ação de Deus, Todo Poderoso. A fé romeira é táctil. Quer ver, pegando; sentir, gestualmente. Ama o chão sagrado, como espaço santificado. $O$ caminho, como passarela do silêncio, entrecortado pela salmodia de repetidas invocações a Deus. Os romeiros do Juazeiro experimentam o mergulho da ansiedade no ritual da deambulação. Seu universo religioso é de pertença à Igreja Católica. A romaria é uma oração nas estradas. São 500, 600 quilômetros percorridos, rumo a Juazeiro, de todo nordeste, carregando suas esperanças, destilando suas dores numa aleluia que encanta: ${ }^{6}$

- Tirei a chave da porta

5 BARRETO, Pe. Murilo de Sá. Romarias; ascese nas estradas em busca do "lugar santo". In: A vida em Cristo e na Igreja. Setembro-outubro 1981. n. 47, p. 3.

6 Ibidem. 
botei os pés no caminho

prá visitar Juazeiro,

pedir a bênção a meu padrinho.

Em Juazeiro, a romaria dá voz aos romeiros. Cantam o que sentem. Sentem o que cantam. Celebram. Sentem-se agentes. A romaria é uma festa. O Santuário da Mãe das Dores é uma casa iluminada, clara. Colhe as lágrimas e o suor da vida e os transforma em compromisso que testemunha, como se retrata em todo o belo livro do Pe. Murilo, que foi pároco em Juazeiro por muitos anos. ${ }^{7}$

Em suas romarias, os romeiros vivem a totalidade e a inteireza do seu ser, sem dicotomia entre corpo e alma. A afetividade, as emoções, os pensamentos, a memória estão em relação profunda e dialética com os sentidos corporais. Na romaria estão envolvidos o corpo, o psiquismo, o espírito, a memória, os sentidos, os sentimentos, as emoções, o afeto, a razão, a alegria, a esperança, a tristeza, o amor, a decepção, a angústia, a féSendo seres humanos, somos chamados a vivenciar nosso corpo e todo o nosso ser em sua dimensão espiritual. Somos chamados a dançar, escrever, comer e beber, orar e celebrar, não "fora do corpo", mas "no" corpo, deixando que as energias psíquicas e espirituais (a alma!), brotando do corpo, nos levem a expressar e experienciar o intangível, o invisível, o inominável, a presença escondida, o mistério. "Fora do corpo" deixamos de ser gente e arriscamos de desencontrar d'Aquele que se fez "corpo", se fez "carne", se fez "história" para se encontrar conosco e nos fazer entrar no mistério da comunhão. ( Cf. Jo 1,14-18; 1Jo1,1-4. $)^{8}$

A ritualidade e linguagem simbólica evocam no romeiro a dupla face da atração e do temor - "fascinosum et tremendum" - do Mistério: arrebatamento e temor; proximidade e distância, êxtase e martírio. É a dinâmica da Liturgia, desde sempre, em todos os lugares, em todos os povos. O

7 Cf. BARRETO, Francisco Murilo de Sá. Padre Cícero. São Paulo: Loyola, Coleção. "nossos padres" 1, 2002.

8 BUYST, lone. O segredo da liturgia: mística 'no' corpo. In: Revista de liturgia, n. 202, julho/ agosto 2007, p. 19. 
mistério se faz presente no símbolo, sendo que a linguagem simbólica é o recurso fundamental para que haja a relação com o sagrado. Padre Murilo, na sua descrição já citada dos romeiros, diz que os romeiros são "pessoas que pouco colocam de racionalização na expressão de sua fé". Eles não segmentam a vida; mas a unificam. Não se preocupam com o "como" e sim com "o que" as coisas são. O "como" separa, re-parte, segmenta. "O que" implica na totalidade. Há o predomínio da ação sobre a teorização. Por isso diz o Pe. Murilo que a fé romeira é táctil: ao rezar fazem promessas para louvar, fazem festa, para falar, atuam.

A fé do romeiro se expressa pelo sentimento e pela ação carregada de vida e de sentido, de uma sabedoria única e explicita a linguagem poética e o excesso de sentido, próprio do símbolo e da linguagem simbólica. Padre Cícero era como a lâmpada e Deus a energia: quando Padre Cícero agia, parecia que era Deus mesmo que agia nele! Ele era como a roupa e Deus o corpo!, dizia um romeiro.

Linguagem simbólica que nos surpreende e nos encanta; síntese mística de fé e vida na "poesia" romeira, ação do Espírito no coração dos pobres que vivem e cantam as maravilhas do Senhor.

\section{SEGUNDA PARTE}

Nesta segunda parte, a proposta é contribuir na reflexão que está em pauta, aprofundarmos conteúdos, a serviço da ciência litúrgica e da animação da vida litúrgica nas nossas comunidades.

\section{I - LITURGIA ROMEIRA FORA DO SANTUÁRIO}

"Que alegria quando me disseram: Vamos à casa do Senhor" (SI 121,1)

a) A viagem. "Caminhar juntos" para o Santuário.

A romaria é ação do Povo de Deus, Povo Sacerdotal que caminha com fé e piedade para um lugar que evoca a presença e o poder da Graça de Deus. Caminha-se com outras pessoas, normalmente em grupos organizados, sob a "presidência" do (a) "fretante", aquele (a) que está à frente e zela pelo 
bom êxito da romaria, como um servidor. Quem convida para participar da romaria é Jesus Cristo, através da sua Mãe. Ele e Ela são a causa da Festa dos romeiros na cidade do Pe. Cícero, a "Jerusalém celeste" dos nordestinos. Para Juazeiro acorre um povo de romeiros, os filhos da Promessa, para celebrar e receber a Bênção da Nova e Eterna Aliança, sobretudo através da celebração do Sacramento da Penitência e da Eucaristia.

b) Povo de Deus reunido na fé.

"Bendito seja Deus que nos reuniu".

Nas romarias de Juazeiro do Norte, os romeiros chegam em caravanas organizadas, de lugares distantes e diferentes. São guiados por uma Estrela que é Nossa Senhora das Dores, a grande devoção que o Padim Cícero transmitiu aos seus "romeirinhos". O objetivo comum é chegar como romeiros à Terra da Mãe das Dores e aí integrar a grande assembléia dos filhos de Deus e de Maria para a celebração da fé da Igreja. Já no caminho, os romeiros fazem das suas caravanas um ensaio de experiência de "assembléia litúrgica": a vida fraterna, o serviço da liderança e outros serviços prestados por quem se preocupa com o bem-estar dos companheiros, a partilha de alimentos, os gestos de atenções recíprocas, os cantos, as preces etc. Nos caminhões "pau de arara", nos ônibus ou nas viagens a pé, os romeiros sabem que estão juntos não por um acaso, mas por um chamado de Deus, da Mãe das Dores e do Pe. Cícero. São pessoas batizadas, Povo de Deus reunido em nome da Trindade. Os romeiros defendem sua identidade católica, pertencem à Igreja de Jesus Cristo, Igreja da qual o Pe. Cícero faz parte.

c) O corpo, durante a viagem, assim como durante os dias da romaria, é o instrumento de purificação pela penitência e pelo sofrimento. Os incômodos e o desconforto das longas viagens preparam os romeiros para a alegria da chegada a Juazeiro. Também, o corpo é o albergue da emoção que o romeiro carrega e exprime quando canta os benditos, quando se relaciona com os outros romeiros. Há uma ansiedade diz o Pe. Murilo, na peregrinação rumo à Terra da Mãe de Deus. Os sentidos estão todos alertas para entender, perceber, guardar na memória cada momento, em intensidade.

d) O tempo da romaria é diferente do corre-corre cotidiano. É tempo de gratuidade e de festa. É a eternidade prefigurada e antegozo do céu. O desejo de chegar logo à cidade-santuário da Mãe das Dores faz que durante a viagem, todo o resto fique em suspenso, porque o envolvimento na romaria 
é total. "Esquece-se de tudo, até da família", dizia Arlene no depoimento já citado. O tempo e o espaço, na romaria, tornam-se sacramentos de comunhão com Deus, para que falem d'Ele e comuniquem a Sua graça.

e) Os lugares da visitação são tidos pelos romeiros como sagrados, mesmo os que não são lugares de culto. Por sinal, toda a cidade de Juazeiro é para os romeiros uma cidade-santuário e, como tal, é respeitada, pois nela habita a glória de Deus. A relação com o lugar sagrado é dialética. É levar e deixar. Deixar de si. O romeiro deixa os pedidos de ajuda, suas angústias, seus problemas, suas alegrias, suas curas... as salas de ex-votos são provas disso. Como também deixam seu nome, seu pedido, seu desejo, escritos na grande estátua do Padre Cícero. Significativo para a visitação dos romeiros, além da Casa do Pe. Cícero, do Horto, da estátua e do Casarão-Museu, é o Santo Sepulcro, no alto da Serra do Catolé. Ali, existem muitas pedras enormes, e algumas capelinhas de antigos beatos que viviam naquele lugar. As orações em tais capelas são acompanhadas por rituais, de acordo com os significados atribuídos a cada grupo de pedras. Em uns rituais, o romeiro deve passar (ritual milenar) por entre duas pedras para se certificar que não tem pecado. Em outros, passar o dedo numa inscrição "feita pelo Padre Cícero" na própria pedra. Outro grupo de pedras é o túmulo de Jesus Cristo etc. Em última análise, é fazer memória: dos que ali viveram, dos seus próprios antepassados que ali já estiveram e realizaram a mesma performance. Estar no "Santo Sepulcro", cumprir ali os rituais, é também fazer história. É fazer memória, também com o corpo. As pedras de Nossa Senhora curam as dores. Outras, mediante determinados gestos, purificam. Outras remetem a outros mundos, como a Jerusalém.

f) $\mathrm{O}$ toque. Nas visitas aos diversos lugares da cidade consagrados pelos romeiros e pela memória do Pe. Cícero, os romeiros tocam em cada objeto significativo. Pe. Murilo dizia que o romeiro "quer ver, pegando". Ver só não basta. É preciso sentir com o tato, cheirar, perceber a emoção que o objeto traz consigo. Mas o toque não é um simples encostar a mão. $O$ tocar é conhecer. Na liturgia romeira, o toque é caminho de mistagogia. É o estímulo para entrar em contato profundo com o objeto. Sentem o significado do objeto. Os olhos fechados, as rugas de concentração na testa, muitas vezes o tremor do corpo todo indicam a relação sentida e vivida, a inter-relação. O relacionamento familiar com o divino inclui a necessidade de ver, ouvir, contemplar, tocar, beijar, apalpar com as mãos (Cf. 1 Jo 1,1). A 
fé e a devoção expressam-se com o corpo inteiro. A religião é constituída, antes de tudo, de gestos ou ritos, isto é: de expressão corporal.

Existe sempre o perigo de entender a liturgia como um acontecimento "automático", algo que acontece na "exterioridade", "fora" de nós. Na verdade, é preciso "subjetivar" a objetividade da liturgia, entrar pessoalmente no mistério celebrado (este é o sentido de "participar"). A ação ritual existe para ativar em nós e aprofundar nossa comunhão pessoal, interior, espiritual com Jesus Cristo e com o Pai, no Espírito Santo. O mistério celebrado deve nos levar cada vez mais profundamente à experiência do mistério "escondido" no "coração" de nossa realidade pessoal e social e, a partir daí, nos levar à missão, ao seguimento. Sem esta ligação "fora/dentro" a liturgia se reduz a mero formalismo, ritualismo. ${ }^{9}$

Qualquer lembrancinha comprada em Juazeiro recebe a bênção do Pe. Cícero pela relação que os romeiros fazem do objeto com algo que pertenceu ao padre, seja sua cama, seja seu túmulo. O romeiro acredita no Padrinho, acredita que a bênção dele se realiza.

\section{A LITURGIA ROMEIRA NO SANTUÁRIO}

Durante mais de um século, os romeiros e as romeiras testemunharam a presença do Deus vivo na capelinha de Nossa Senhora das Dores em Juazeiro do Norte, hoje Santuário Diocesano e Basílica Menor. Os romeiros têm a "Matriz do Juazeiro" como ponto de chegada e de partida da romaria.

O primeiro gesto da liturgia romeira ao chegar na Terra da Mãe de Deus, é visitar a Matriz de Nossa Senhora das Dores. Enfim, as caravanas de peregrinos entram em procissão na Casa de Deus e de Nossa Senhora. Ingressam no Santuário cantando seus benditos carregados de sentimento e de piedade. Com o chapéu de palha na cabeça, símbolo distintivo dos romeiros do Pe. Cícero dirigem-se até o Altar. Não raramente, levam os andores dos Santos Padroeiros de suas comunidades, quase a dizer que aquela romaria é completa e abençoada: aí está simbolicamente todo o

$921^{\text {a }}$ Semana de Liturgia - 15 a 19 de Setembro de 2007. In: http://www.teologia-assuncao. br/cursos/5outros/liturgia/mistagogia.lone.doc 
Povo de Deus, os Santos do céu e a Igreja que caminha para o céu. Aos pés de Nossa Senhora das Dores, agradecem a viagem, louvam a Deus e fazem suas preces. Quem dirige esta procissão de entrada é o responsável (fretante) da romaria.

Enfim, na Casa de Deus e de Nossa Senhora. Na presença do Mistério.

Quais os sentimentos ao entrar no Santuário?

O romeiro fazendo a caminhada por muitos e muitos quilômetros, entrando na igreja de joelhos ou soltando o foguete de sua promessa, encontra-se plenamente saciado de sua carência espiritual. (...) A caminhada, como qualquer outra promessa, é ato transcendental de penitência e humildade. Esmaga-se o corpo no cansaço, liberta-se o espírito pela satisfação da graça recebida e da promessa cumprida". ${ }^{10}$

Nesse sentido, a romaria aparece como um ritual de iniciação, uma passagem da morte para a vida, da distância para a proximidade e a identificação mística com a divindade.

O romeiro avança de joelhos até o Altar, canta benditos, de braços estendidos olha para a imagem de Nossa Senhora das Dores, reza com o chapéu de palha na cabeça. É o ponto alto da peregrinação. O romeiro se realiza. O seu sonho já é realidade. Está feliz, pois se sente em casa, junto com Jesus, com Maria e com os outros irmãos romeiros. Foi perseverante na fé e na esperança. Agora é tempo de vivenciar a graça e a emoção do encontro.

Cumprindo suas promessas, o romeiro sabe que Deus, por primeiro, é fiel e cumpre a sua aliança de amor e de fidelidade.

No Santuário, lugar da Memória das maravilhas do Senhor, o romeiro "recorda os grandes feitos de Deus na sua vida e agradece a Deus Criador e Pai que cuida dos seus filhos, dá alimento com fartura aos que têm fome e sede de justiça; protege e ampara os que sofrem, zela pela alegria dos seus amados. Contempla a imagem de Nossa Senhora das Dores, reza em silêncio, faz a recordação da vida, eleva suas preces, canta hinos. Mas, sobretudo, o romeiro se coloca em atitude de escuta atenta e devota diante

10 JACOB, A. S. A Santíssima Trindade do Barro Preto. 2000, 320323 
da Palavra de Deus. É a memória do Povo de Deus, a Bíblia Sagrada, mostrada, lida, meditada, aplaudida e celebrada. Particularmente nas celebrações eucarísticas. O Livro Sagrado é o Mistério de uma Presença: de Aliança, nas mãos, nos olhos e no coração do povo, a maioria ainda analfabetos, mas que - como Maria - gravam no coração e meditam tudo o que Jesus diz. Afinal, ser romeiro da Mãe das Dores e do Pe. Cícero é abraçar uma causa e viver um recado: Fazei tudo para "visitar" (é assim mesmo que eles dizem) a minha Mãe das Dores e o Pe. Cícero, fazem memória da "ação poderosa de Deus na história, que está na origem do povo da aliança e da fé de cada um dos crentes"11

Enfim, "os romeiros testemunham a iniciativa de Deus que os chama para a casa que Ele edificou e os convida para unirem-se a Si e mudar-lhes o coração e a vida"12

\section{TERCEIRA PARTE}

\section{I - PROVOCANDO...}

a) O Diretório sobre piedade popular e Liturgia - Princípios e Orientações publicado em 2002, pela Congregação para o Culto Divino e a disciplina dos Sacramentos, alerta:

Deve ser superado o equívoco de que a Liturgia não seja "popular" - a renovação conciliar procurou promover a participação do povo na celebração litúrgica, incentivando modos e espaços (cânticos, envolvimento ativo, ministérios leigos...) que, em outros tempos, suscitaram orações alternativas ou substitutivas à ação litúrgico. ${ }^{13}$

11 CONSELHO PONTIFÍCIO PARA A PASTORAL DOS MIGRANTES E ITINERANTES. O SANTUÁRIO-Memória, Presença e Profecia do Deus vivo, n. 4, Cidade do Vaticano, 8 de Maio de 1999.

12 Idem

13 CONGREGAÇÃO PARA O CULTO DIVINO E A DISCIPLINA DOS SACRAMENTOS. Diretório sobre a piedade popular e liturgia: princípios e orientações. São Paulo: Paulinas, 2003, $\mathrm{n}^{\circ}$ 11 
Na Conferência à Imprensa, quando da apresentação do Diretório, o Cardeal Jorge Artur Medina Estévez, Prefeito da Congregação para o Culto Divino e a disciplina dos Sacramentos sublinhou que,

juntamente com a celebração litúrgica, que é "fonte e ápice da vida da Igreja" () a tradição testemunha uma grande riqueza de modalidades de oração particular e comunitária: é o âmbito geralmente denominado como "piedade popular" ou "religiosidade popular" ou "devocional", que tem uma influência significativa sobre a vida espiritual dos fiéis em geral. ${ }^{14}$

Importa clarificar - recordou - o relacionamento necessário que deve existir entre Liturgia e piedade popular. Por vezes, a contraposição que se faz entre ambas, conota a Liturgia com a norma rígida e a piedade popular com a espontaneidade criativa. Mas esta é uma generalização "muito parcial", embora com "algo de verdadeiro". Por isso,

se sentiu a necessidade de redigir um Documento que realçasse os princípios e oferecesse indicações e orientações em ordem a desenvolver a harmonização entre Liturgia e piedade popular já desejada pelos Padres do Concílio Vaticano II. ${ }^{15}$

b) A Instrução afirma o "primado" e a "eminência da Liturgia em relação a qualquer outra possível e legítima forma de oração cristã"16. Contudo, um olhar evangélico, na linha da ação de graças de Jesus a respeito dos segredos de Deus revelados aos pequeninos (Mt 11, 32-35), não seria capaz de enxergar na "liturgia romeira" a "eminência da Liturgia", em vez de relegá-la apenas ao nível de "legítima forma de oração"?

c) A "Liturgia Romeira" não poderia ser encarada como um "sinal dos tempos", capaz de contribuir para a "conversão" de uma Liturgia que de tão "eminente" torna-se "distante" e deixa de ser coisa do Povo de Deus, para ser coisa de poucos, de clérigos que mais se sentem "donos" que servidores ou administradores dos Mistérios de Deus?

\footnotetext{
14 MEDINA ESTÉVEZ, Card. Jorge A. Conferenza stampa di presentazione del documento "Direttorio su pietà popolare e liturgia. Principi e orientamenti,. 4 de setembro de 2002. http://www.vatican.va:80/roman_curia/congregations/ccdds/documents/rc_con_ccdds_ doc_20020409_conf-stampa-direttorio_it.html

15 Idem

16 Idem
} 
d) Pensando na experiência do "espaço sagrado" na romaria, como organizar nossos espaços celebrativos, permanentes ou ocasionais, de tal maneira que quem chega para a celebração o sinta como chão sagrado, e "sagrado"porque aponta para um mundo diferente, de acolhida e aconchego, de beleza, dignidade e fraternidade, de igualdade e solidariedade, símbolo de um Mundo Novo que precisa acontecer "assim na terra, como no céu", e já se pressente aqui e agora?

e) Vale ressaltar que a Romaria, como "poesia em gestos" (apelo aos princípios da criatividade e da inculturação na celebração do Mistério Pascal), é expressão viva da dimensão da fé partilhada e celebrada no caminho....

Quem sabe, não venha da Romaria uma luz para a ciência litúrgica, para a ASLI, para os agentes de pastoral, iluminando caminhos para a animação da vida litúrgica nas nossas comunidades, visivelmente cansadas e, talvez, até desencantadas. Devolver à Liturgia a força e a alegria de encantar o povo que celebra: eis o desafio. Os romeiros celebram Jesus Cristo com "ardor missionário".

\section{II - QUE LUZES?}

Entre outras:

a) As romarias, expressões da piedade popular, são liturgias "emergentes", que ajudam a Liturgia a valorizar a vida e a cultura da Assembléia. Desde a Constituição Sacrosanctum Concilium do Vaticano II nós falamos disto: participação plena, atenta, devota, frutuosa, interna, externa; respeito à índole do povo; inculturação; criatividade.... Mas ainda estamos longe, apesar dos repetidos apelos que nos são dirigidos pelo Magistério, especialmente para nós, do Brasil e da América Latina.

b) A piedade popular e as romarias, nos advertem que "a formação litúrgica tem como principal tarefa hoje, instituir, constituir o sujeito litúrgico, consciente, comunitário, capaz de celebrar na inteireza do ser e ajudar a tornar significativa a celebração da comunidade". ${ }^{17}$

17 BUYST, I. em Formação Litúrgica, Memória Pessoal, São Paulo, 2006, p. 45. 
A Expressão Litúrgica da Romaria em Juazeiro do Norte - CE

c) A piedade popular e romarias recordam a dimensão mistagógica da Liturgia, insinuando e promovendo o retorno delas nas nossas assembléias litúrgicas. Reeducar o Povo de Deus para viver a Liturgia pela experiência, pois a

Liturgia só se entende com a inteligência do coração. Não compreenderá a liturgia quem nela não penetrar e se envolver pela fé e com amor. A Liturgia, antes de ser ensino, é experiência que passa pelos sentidos, pelo deslumbramento, pela contemplação e pelo envolvimento corporal na ação simbólica. Primeiro experimentamos e depois tentamos explicar, refletir, compreender o que se passou e se viveu na celebração. $A$ experiência da celebração da salvação chama-se de "teologia primeira". A reflexão sobre a experiência vivida, a compreensão do que aconteceu, a sistematização dos dados encontrados e das descobertas feitas chama-se "teologia segunda", ou seja, teologia que estudamos nas salas de aula e que vem escrita em livros. ${ }^{18}$

d) Outra luz que a piedade popular oferece à celebração litúrgica é recordar que

a liturgia está ligada ao corpo e aos sentidos. Temos apenas um simbolismo fundamental, o do corpo humano como expressão da alma humana, e, portanto, o primeiro de todos os símbolos. Todos os outros gestos simbólicos se situam em continuidade com o corpo humano". 19

e) A piedade popular (romarias) e a liturgia deviam se enriquecer mutuamente sem perder suas características. O que não pode perder é a consciência da presença do Senhor, a primazia da Palavra: os atos do povo devem ser uma preparação, prolongação dos mistérios celebrados, como também uma complementação ou até uma personificação nas celebrações e a assistência do Espírito Santo. Por sua vez, a piedade popular pode ajudar a Liturgia quanto à devoção e à afetividade. A piedade popular reveste a mensagem da salvação de poesia, imagens, costumes e tradições da vida - patrimônio religioso e cultural de um povo que reza e celebra a sua fé.

18 DANEELS, G. A Liturgia quarenta anos após o Concílio Vaticano II. In: Doc. Cath. 18-5-2003, p. 16

19 Idem 
f) A piedade popular e as romarias não se contrapõem à Liturgia, mas a preparam, prolongam e complementam.

g) Valorizar e multiplicar na Liturgia a dinâmica psicológico-espiritual do "toque":

$\checkmark$ na entrada no santuário, se poderia resgatar um costume esquecido, o da ablução com água benta, com sentido penitencial de purificação ou de renovação do batismo;

$\checkmark$ o aperto de mão das pessoas ao se reunirem em Assembléia, poderia selar o sentimento de comunhão fraterna;

$\checkmark$ tocar a Bíblia, após a homilia ou a meditação compartilhada, poderia valer como profissão da renovação da Aliança;

$\checkmark$ tocar a bandeja com o pão e o cálice com o vinho, ao passar a procissão do ofertório, poderia expressar a entrega da própria vida, em Cristo, por Cristo e em Cristo;

$\checkmark$ tocar a Mesa, ao sair da Igreja, após o envio e a bênção, poderia ser a expressão final do compromisso missionário ou do desejo de voltar a reencontrar-se com o Pai e com os irmãos e irmãs, em Jesus, no Espírito;

$\checkmark$ Tocar a imagem da Cruz do Ressuscitado, sobretudo em certas datas, poderia selar a adesão de discípulos e missionários...

$\checkmark$ Tocar a imagem de Maria, ícone da Igreja, poderia alimentar a confiança e a obediência à Mãe que nos diz: "Façam tudo o que ele Ihes disser!".

h) Os "benditos" tradicionais de romaria não mereceriam muito maior atenção dos letristas e compositores litúrgicos, no sentido de intuírem o "espírito da coisa"? A dinâmica da letra e da música, o clima espiritual e afetivo desses cantos dei) A importância do "caminhar" não estaria a sugerir um aproveitamento maior e mais cuidadoso da prática de "procissão", no sentido de inspirar muito mais a espiritualidade do Êxodo, o sonho da Terra Prometida, a experiência do Deus-Companheiro?

j) O impressionante e espontâneo "silêncio" dos romeiros em tantos momentos da romaria, não estaria a sugerir, por exemplo, um silêncio motivado por palavras inspiradoras, acompanhado de gestos como a mão no 
coração, ou ajoelhar-se, em momentos penitenciais... a prática do silêncio após a proclamação da leitura bíblica, evitando-se qualquer fala de imediato, até que as palavras sagradas assentem no fundo dos corações?

k) O "calendário" anual do romeiro precisaria ser consciente e organicamente integrado ao Ano Litúrgico, de tal maneira que o Mistério Pascal pudesse ser celebrado com toda a riqueza de matizes e sem quebra de continuidade?

Eu disse que estas eram umas entre outras provocações... A lista está em aberto...

\section{POR FIM...}

Vida e liturgia têm recíproca relação dialética. A vida cristã funda-se sobre duas coisas: cultus e charitas. ${ }^{20}$

Uma famosa frase de Santo Agostinho, retomada em Lumen Gentium, $n^{\circ}$ 8, diz: "A lgreja prossegue a sua peregrinação entre as perseguições do mundo e a consolação de Deus". ${ }^{21}$

E entre as consolações, seja no passado como nos nossos dias, estão as testemunhas: ou seja, os mártires, os que deram sua vida e, também, os que creem e dão as razões de sua fé e de sua esperança, vivendo dignamente e santamente. Disto, a Piedade Popular é testemunha: olhando para o que há de vir, os romeiros e romeiras de todos os lugares e de todos os santos, são imagem da Igreja peregrina que avança no caminho da Vida e salvação: Povo romeiro que caminha celebrando e celebra caminhando. "Caminhamos na estrada de Jesus" celebrando a Páscoa do Senhor em nossa vida. Somos "Igreja que caminha nas estradas do mundo rumo ao céu, cada dia renovando a esperança de chegar junto a vós, na vossa paz" (Oração Eucarística V).

Dom Fernando Panico.

Bispo do Crato - CE. Tem formação litúrgica e atua há anos como estudioso dos fenômenos que envolvem as romarias de Juazeiro do Norte - CE.

\footnotetext{
20 Idem

21 SANTO AGOSTINHO, Civitas Dei, XVIII, 51,2
} 